\title{
Calcium Control of Neurotransmitter Release
}

\author{
Thomas C. Südhof \\ Department of Molecular and Cellular Physiology, and Howard Hughes Medical Institute, Stanford \\ University School of Medicine, Stanford, California 94305 \\ Correspondence: tcs1@stanford.edu
}

Upon entering a presynaptic terminal, an action potential opens $\mathrm{Ca}^{2+}$ channels, and transiently increases the local $\mathrm{Ca}^{2+}$ concentration at the presynaptic active zone. $\mathrm{Ca}^{2+}$ then triggers neurotransmitter release within a few hundred microseconds by activating synaptotagmins $\mathrm{Ca}^{2+}$. Synaptotagmins bind $\mathrm{Ca}^{2+}$ via two $\mathrm{C} 2$-domains, and transduce the $\mathrm{Ca}^{2+}$ signal into a nanomechanical activation of the membrane fusion machinery; this activation is mediated by the $\mathrm{Ca}^{2+}$-dependent interaction of the synaptotagmin C2-domains with phospholipids and SNARE proteins. In triggering exocytosis, synaptotagmins do not act alone, but require an obligatory cofactor called complexin, a small protein that binds to SNARE complexes and simultaneously activates and clamps the SNARE complexes, thereby positioning the SNARE complexes for subsequent synaptotagmin action. The conserved function of synaptotagmins and complexins operates generally in most, if not all, $\mathrm{Ca}^{2+}$-regulated forms of exocytosis throughout the body in addition to synaptic vesicle exocytosis, including in the degranulation of mast cells, acrosome exocytosis in sperm cells, hormone secretion from endocrine cells, and neuropeptide release.

Cynaptic transmission is initiated when an Saction potential invades a nerve terminal, opening $\mathrm{Ca}^{2+}$ channels, which gate a highly localized, transient increase in intracellular $\mathrm{Ca}^{2+}$ at the active zone (Fig. 1A). $\mathrm{Ca}^{2+}$ triggers synaptic vesicle exocytosis, thereby releasing the neurotransmitters contained in the vesicles and initiating synaptic transmission. This fundamental mechanism was discovered in pioneering work on the neuromuscular junction by Katz and Miledi (1967). Its precise time course was studied in many "model" synapses, including giant squid axon synapses (Augustine et al. 1985) and rat cerebellar parallel fiber synapses (Sabatini and Regehr 1996), but characterized in greatest detail in the calyx of Held synapses in the brainstem (Fig. 1B; reviewed in Meinrenken et al. 2003). Overall, these high-resolution electrophysiological studies on neurotransmitter release revealed that a presynaptic action potential is tightly coupled to $\mathrm{Ca}^{2+}$ influx and synaptic vesicle fusion, such that under physiological conditions, $\mathrm{Ca}^{2+}$ triggers fusion in a few hundred microseconds, or possibly even in less than 100 microseconds (Sabatini and Regehr 1996).

The amazing speed and precision of $\mathrm{Ca}^{2+}$ triggered neurotransmitter release raised the question of how such speed might be possible-how can $\mathrm{Ca}^{2+}$ induce exocytosis in a few hundred microseconds, on the same timescale as the gating of an ion channel? As we will

Editors: Morgan Sheng, Bernardo Sabatini, and Thomas Südhof

Additional Perspectives on The Synapse available at www.cshperspectives.org

Copyright (C) 2012 Cold Spring Harbor Laboratory Press; all rights reserved; doi: 10.1101/cshperspect.a011353

Cite this article as Cold Spring Harb Perspect Biol 2012;4:a011353 
T.C. Südhof

A

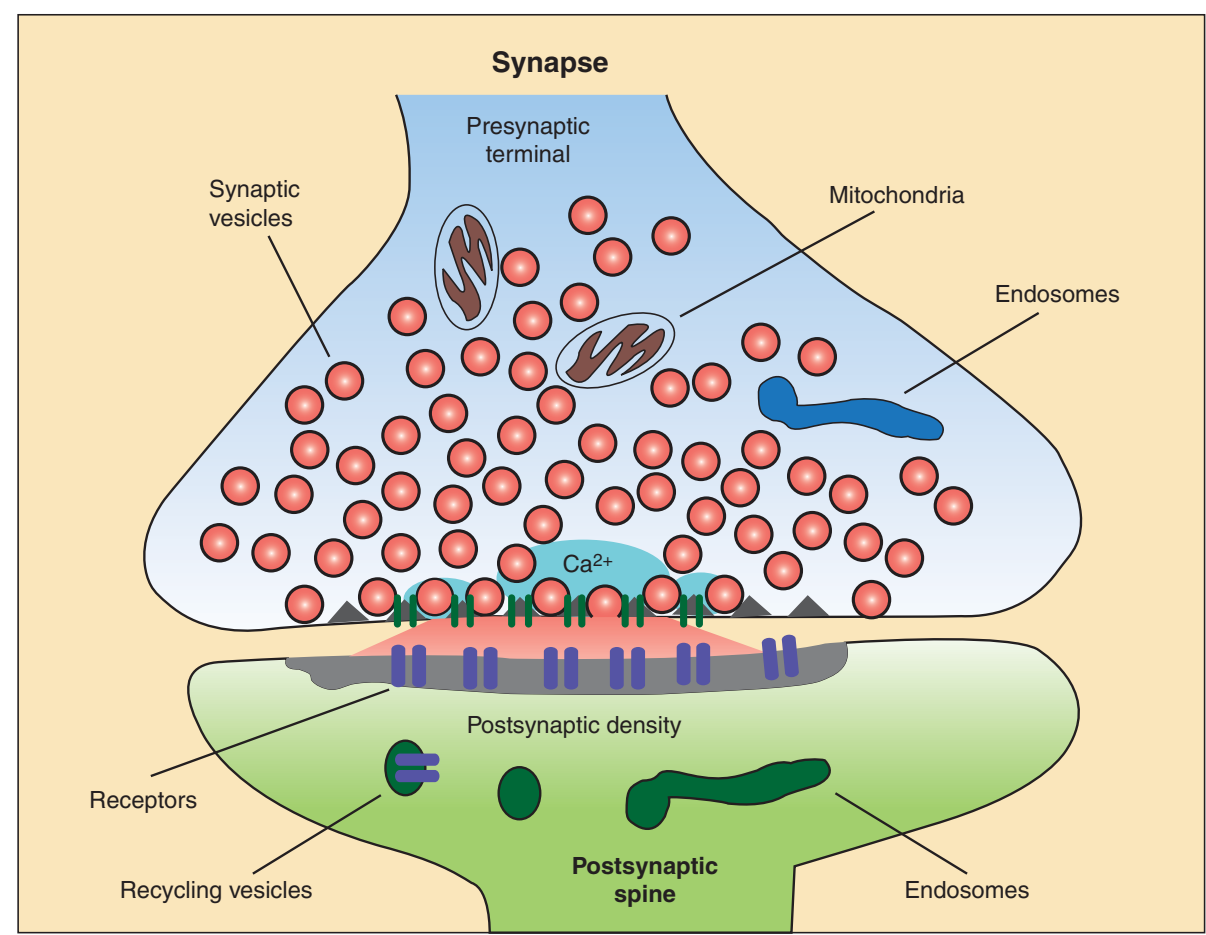

B
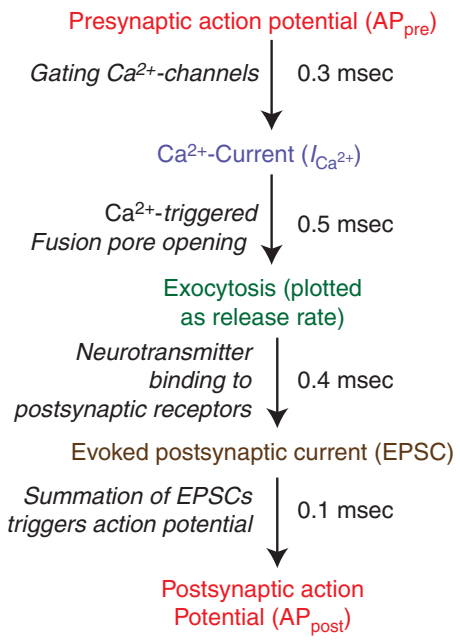

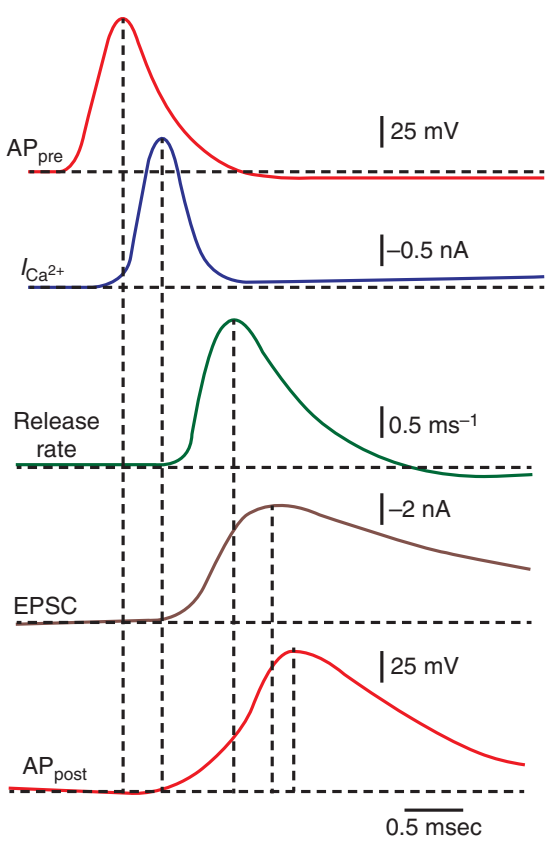

Figure 1. Principle and time course of $\mathrm{Ca}^{2+}$-triggered synaptic transmission. (A) Schematic diagram of a synapse illustrating the localized influx of $\mathrm{Ca}^{2+}$ at the active zone (red = secreted neurotransmitters). (B) Schematic illustration of the sequence and time course of synaptic transmission as measured by simultaneous pre- and postsynaptic patch-clamp recordings at the calyx of Held synapse. Note that $\mathrm{Ca}^{2+}$ currents and EPSC are shown inverted. (Images are modified from Südhof 2004 and Meinrenken et al. 2003.) 
describe in this review, the speed and precision of release are mediated, at least in part, by the properties of the $\mathrm{Ca}^{2+}$ sensor synaptotagmin (Syt) and its cofactor complexin. Moreover, increasing evidence indicates that the principal mechanism of $\mathrm{Ca}^{2+}$-triggered exocytosis, although not the organization of this mechanism, is conserved in other, slower forms of $\mathrm{Ca}^{2+}$. induced exocytosis. Thus, the Syt-based fusion apparatus emerges as a general paradigm that accounts for most $\mathrm{Ca}^{2+}$-regulated exocytosis in eukaryotic cells.

In addition to normal action potentialevoked neurotransmitter release, synapses exhibit two additional forms of $\mathrm{Ca}^{2+}$-dependent synaptic exocytosis: spontaneous "mini" release and asynchronous release (Pang and Südhof 2010). Spontaneous mini release was discovered by Katz (Fatt and Katz 1952), and is thought to represent the background activity of a nerve terminal that is triggered by spontaneous $\mathrm{Ca}^{2+}$ fluctuations. Although the biological significance of spontaneous release remains debated, its presence can be observed in all neurons. When calculated on a per-synapse basis, spontaneous release occurs only once every 23 hours at an individual excitatory synapse of a pyramidal neuron in the CA1 region of the hippocampus, and approximately once every $3 \mathrm{~min}$ at individual inhibitory synapses. Asynchronous release is undetectable in most synapses under physiological conditions, but becomes apparent when the principal Syt $\mathrm{Ca}^{2+}$ sensor for regular release is ablated (Geppert et al. 1994). Some inhibitory synapses exhibit a slow form of release on repetitive stimulation (Hefft and Jonas 2005), which may represent either genuine physiological asynchronous release or simply synaptotagmindependent delayed release.

\section{STRUCTURE AND BIOCHEMICAL PROPERTIES OF SYNAPTOTAGMINS}

Syts are defined as proteins containing a short amino-terminal noncytoplasmic sequence followed by a transmembrane region, a central linker sequence of variable length, and two carboxy-terminal C2-domains that account for the majority of the protein (Fig. 2A; Perin et al. 1990). Sixteen genes encoding canonical Syts are expressed in mammals; in addition, mammals contain a Syt-related gene encoding a similar protein (the so-called $\mathrm{B} / \mathrm{K}$ protein) that lacks a transmembrane region, and is occasionally called Syt17. Synaptotagmins are evolutionarily conserved, and invertebrates also express multiple Syt isoforms. However, synaptotagmins are absent from plants and unicellular eukaryotes, suggesting that they evolved at the same time as animals. Moreover, a large family of Syt-like proteins is expressed in animals; these proteins also contain two C2domains, but will not be discussed here further (see Pang and Südhof 2010). Syt1, Syt2, Syt9, and Syt12 are present on synaptic vesicles and on secretory granules in neuroendocrine cells; the latter also contain Syt7. In addition, Syt10 was recently found on secretory vesicles containing IGF-1 in olfactory mitral neurons (Cao et al. 2011); Syt4 was localized to the trans-Golgi complex, synaptic vesicles, and postsynaptic organelles, and may be widely distributed in neuronal organelles (reviewed in Südhof 2004); and Syt7 was additionally localized to "secretory lysosomes" in nonneuronal and nonendocrine cells (Andrews and Chakrabarti 2005). Other Syts appear to be primarily localized to transport vesicles, although some Syt isoforms are enriched on the plasma membrane (Butz et al. 1999), and the identity of many of the Syt-containing vesicles remains unknown.

C2-domains were named as sequence motifs in protein kinase $\mathrm{C}$ isoforms (Coussens et al. 1986), but their functional activity as autonomously folded $\mathrm{Ca}^{2+}$-binding domains was first identified in Syt1 (Davletov and Südhof 1993). The atomic structures of the C2A-domain of Syt 1, the first C2-domain structure determined (Sutton et al. 1995), revealed that C2-domains are composed of a stable $\beta$-sandwich with flexible loops emerging from the top and bottom (Fig. 2B); all subsequently determined C2-domain structures described a similar fold. $\mathrm{Ca}^{2+}$ binds exclusively to the top loops of the $\mathrm{C} 2$-domains, which form binding sites for two to three $\mathrm{Ca}^{2+}$ ions in close vicinity (Shao et al. 1996). Although not all C2-domains 
T.C. Südhof

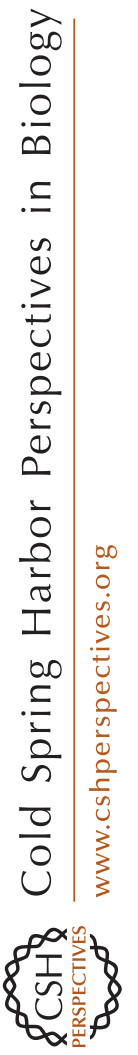

A

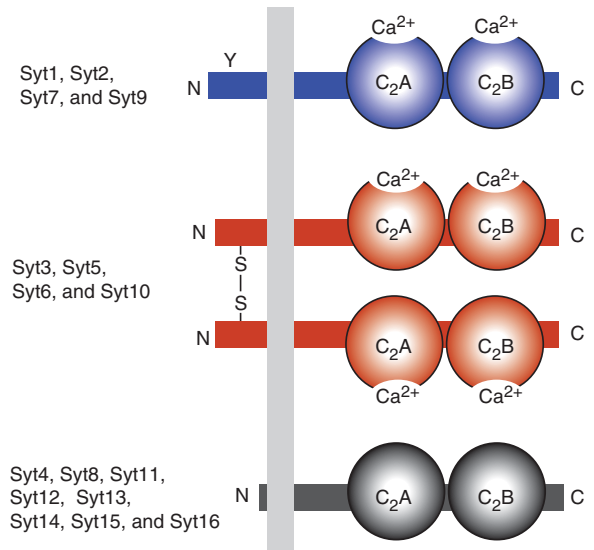

B
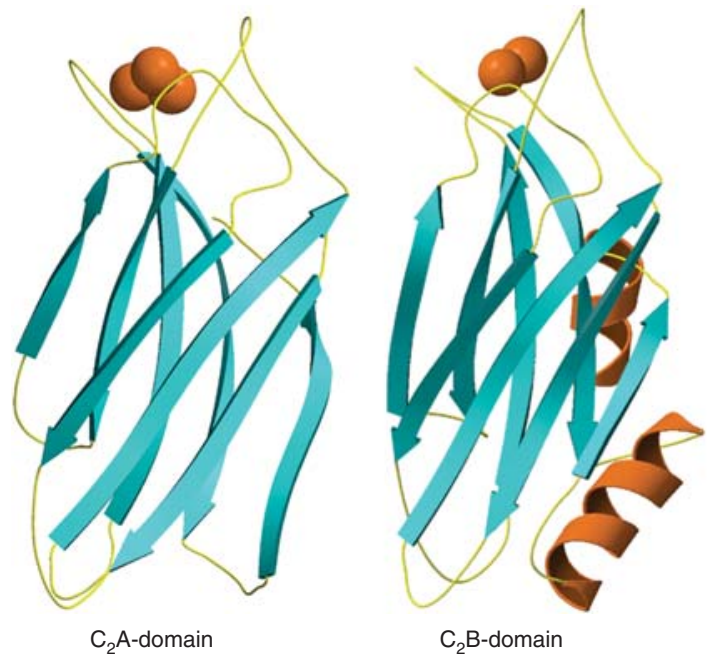

C

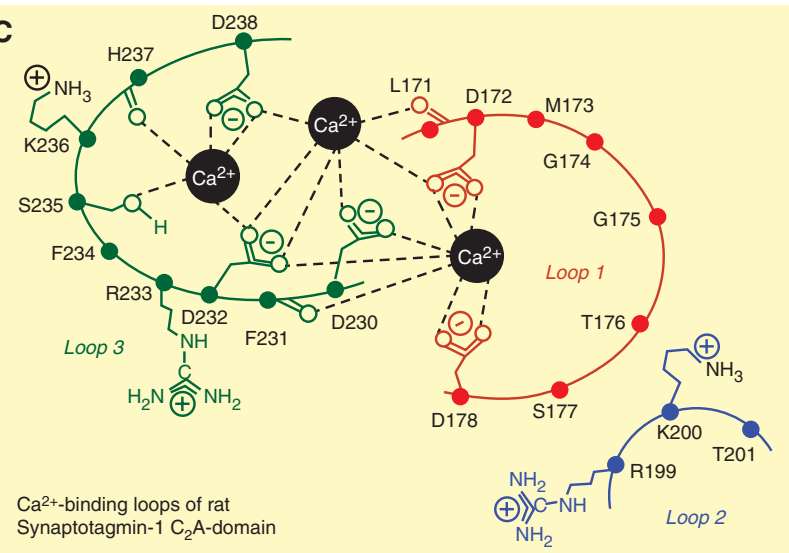

Figure 2. Structures and $\mathrm{Ca}^{2+}$-binding properties of synaptotagmins. $(A)$ Canonical domain structures and classification of synaptotagmins. Mammals express 16 synaptotagmins composed of an amino-terminal transmembrane region preceded by a short noncytoplasmic sequence and followed by a variable linker sequence and two C2-domains; in addition, a 17th related protein called B/K-protein contains the same domain structure but an amino-terminal lipid anchor instead of the transmembrane region (see Pang and Südhof 2010, for a discussion of additional synaptotagmin-related proteins). (See facing page for legend.) 
bind $\mathrm{Ca}^{2+}$ (see below), all of those that do and have been studied in detail contain the same $\mathrm{Ca}^{2+}$-binding site architecture, with the $\mathrm{Ca}^{2+}$ ions ligated primarily by aspartate side chains (Fig. 2C). C2-domains are now recognized as general $\mathrm{Ca}^{2+}$-binding modules which are found in a large number of signal transduction and membrane trafficking proteins.

Approximately half of all C2-domains lack the canonical aspartate residues required for $\mathrm{Ca}^{2+}$ binding, including the C2A-domains of Syt4 and Syt11 (von Poser et al. 1997), and all C2-domains of Syt8 and Syt12-Syt16, which are thus thought to be $\mathrm{Ca}^{2+}$ independent. Even the C2B-domains of Syt4 and Syt11 which include all of the requisite $\mathrm{Ca}^{2+}$-binding sequences were found to be unable to bind $\mathrm{Ca}^{2+}$ (Dai et al. 2004). This initially surprising result was explained by the atomic structure of the Syt 4 C2B-domain, which showed that the canonical $\mathrm{Ca}^{2+}$-binding residues in the top loops of the domain are too far apart to be able to ligate $\mathrm{Ca}^{2+}$ (Dai et al. 2004). Thus, the 16 mammalian Syts can be broadly classified into $\mathrm{Ca}^{2+}$-dependent and $\mathrm{Ca}^{2+}$-independent groups (Fig. 2A). The first group can be further subclassified based on whether or not their amino-terminal noncytoplasmic sequences contain disulfidebonded cysteine residues (Fukuda et al. 1999). Similarly, the second group can be subclassified based on evolutionary conservation and sequence homologies, which reveal two sets of evolutionarily conserved synaptotagmins formed by Syt 4 and Syt11 and by Syt14-16, and into a heterogeneous set of nonconserved synaptotagmins (Syt8, Syt12, and Syt13).

Initial studies on Syt1 revealed that both of its C2-domains bind to phospholipids in a $\mathrm{Ca}^{2+}$-dependent manner (Davletov and Südhof 1992; Fernandez et al. 2001), and that they bind to SNARE proteins (Bennett et al. 1992; Chapman et al. 1995; Li et al. 1995). Syt1 binding to phospholipids requires $\mathrm{Ca}^{2+}$ and negatively charged phospholipids, with phosphatidyl-inositolphosphates being most effective (Pang et al. 2006). Interestingly, the intrinsic $\mathrm{Ca}^{2+}$ affinity of the Syt 1 C2-domains is relatively low (millimolar), but the presence of negatively charged phospholipids increases their apparent $\mathrm{Ca}^{2+}$ affinity by two to three orders of magnitude. This probably occurs because the $\mathrm{Ca}^{2+}$-coordination spheres of the Syt1 C2-domains are incomplete, but are completed by the negatively charged phospholipid headgroups during $\mathrm{Ca}^{2+}$ dependent phospholipid binding (FernándezChacón et al. 2001; Fernandez et al. 2002). In contrast to the $\mathrm{Ca}^{2+}$-dependent interaction of Syt1 with phospholipids, its binding to SNARE proteins and SNARE complexes is less well understood. There seems to be a direct interaction of the Syt1 C2-domains with syntaxin-1 that is greatly enhanced by $\mathrm{Ca}^{2+}$ (Li et al. 1995); moreover, Syt1 also binds to assembled SNARE complexes in a $\mathrm{Ca}^{2+}$-dependent manner (Pang et al. 2006). However, the interaction of Syt 1 with SNARE complexes is highly sensitive to ionic strength in that it becomes $\mathrm{Ca}^{2+}$ independent at lower ionic strength, and at least some

Figure 2. (Continued) Eight synaptotagmins bind $\mathrm{Ca}^{2+}(\mathrm{Syt} 1,2,3,5,6,7,9$, and 10; blue and red); the remaining synaptotagmins do not (black). The eight $\mathrm{Ca}^{2+}$-binding synaptotagmins fall into two broad classes that differ in the absence (Syt1, 2, 7, and 9; blue) or presence (Syt3, 5, 6, and 10; red) of disulfide-bonded cysteine residues in their amino-terminal sequences. Note that Syt 1 and 2 include an $\mathrm{N}$-glycosylated sequence at the amino terminus (indicated by a "Y"), and that Syt7 is extensively alternatively spliced in the linker sequence (Han et al. 2004). (B) Atomic structures of the C2A- and C2B-domains of Sytl containing bound $\mathrm{Ca}^{2+}$ ions (red spheres) bound to flexible loops formed by an eight-stranded $\beta$-sandwich (from Sutton et al. 1995; Ubach et al. 1998; Fernandez et al. 2001). (C) Structure of the $\mathrm{Ca}^{2+}$-binding sites of the Syt1 C2A-domain (modified from Fernández-Chacón et al. 2001). The Syt1 C2A-domain contains three $\mathrm{Ca}^{2+}$-binding sites, of which the central two are canonical for all $\mathrm{Ca}^{2+}$-binding $\mathrm{C} 2$-domains, whereas the third $\mathrm{Ca}^{2+}$ site on the left is variably observed in C2-domains, and is absent from the Syt 1 C2B-domain. A further $\mathrm{Ca}^{2+}$-binding site that localizes to loop1 on the right is observed in some C2-domains, but is absent from Syt1 and is not shown. Loops refer to the flexible sequences on the top of the Syt1 C2-domain sandwich; the structures of some of the side chains are indicated. 
$\mathrm{Ca}^{2+}$-independent SNARE-complex binding by Syt1 may occur physiologically (Pang et al. 2006).

All Syt isoforms that bind $\mathrm{Ca}^{2+}$ appear to bind to phospholipids and to SNARE proteins in a $\mathrm{Ca}^{2+}$-dependent manner ( $\mathrm{Li}$ et al. 1995; Sutton et al. 1999; Sugita et al. 2002; Hui et al. 2005). Interestingly, at least during $\mathrm{Ca}^{2+}$-dependent phospholipid binding, different Syts exhibit quite different apparent $\mathrm{Ca}^{2+}$ affinities, suggesting that they normally differentially respond to $\mathrm{Ca}^{2+}$ signals (Sugita et al. 2002). The biochemical properties of most $\mathrm{Ca}^{2+}$-independent Syts remain unknown, apart from Syt12, which has been shown to bind to Syt1 on the synaptic vesicle membrane (Maximov et al. 2007).

\section{FUNCTION OF SYNAPTOTAGMINS IN NEUROTRANSMITTER RELEASE}

From the very beginning, Syt 1 was hypothesized to function as a $\mathrm{Ca}^{2+}$ sensor for neurotransmitter release (Perin et al. 1990; Brose et al. 1992; Davletov and Südhof 1993). Knockout (KO) of Syt1 confirmed this hypothesis, showing that the Syt1 deletion abolished fast synchronous neurotransmitter release (Fig. 3A; Geppert et al. 1994). Strikingly, not all $\mathrm{Ca}^{2+}$-stimulated release was abolished in Syt $1 \mathrm{KO}$ neurons, which retained a delayed asynchronous form of release that is increased on repetitive stimulation (Maximov and Südhof 2005). Moreover, release induced by hypertonic sucrose, which is thought to cause the $\mathrm{Ca}^{2+}$-independent exocytosis of all vesicles in the readily releasable pool of a synapse was unchanged, indicating that the Syt1 $\mathrm{KO}$ did not interfere with vesicle fusion as such, but only with the $\mathrm{Ca}^{2+}$ triggering of fusion (Geppert et al. 1994).

Given that eight $\mathrm{Ca}^{2+}$-binding Syts are expressed in neurons, which of these Syts function in neurotransmitter release? A systematic screen of $\mathrm{Ca}^{2+}$-binding Syts for rescue of the Syt1 KO phenotype revealed that only Syt1, Syt2, and Syt9 were capable of rescue (Fig. 3B; $\mathrm{Xu}$ et al. 2007). This result is surprising given the close similarity of $\mathrm{Ca}^{2+}$-binding Syts with each other, but is consistent with the differential expression patterns of Syt1, Syt2, and Syt9, and also explains why Syt1 KO neurons lose all release despite expressing high levels of Syt7, Syt3, and Syt5. Strikingly, Syt1, Syt2, and Syt9 were found to trigger release with quite distinct kinetics, with Syt 2 exhibiting the fastest onset and the fastest decline in release, and Syt9 the slowest onset and the slowest decline (Fig. 3C,D; Xu et al. 2007). The distinct kinetic properties of Syt1, Syt2, and Syt9 fit well with the expression of Syt9 primarily in the limbic system, whereas Syt 2 is primarily expressed in synapses requiring very fast synaptic transmission, such as the auditory system or the neuromuscular junction.

The demonstration that Syt1 is essential for fast $\mathrm{Ca}^{2+}$-triggered neurotransmitter release was consistent with the notion that Syt 1 functions as a $\mathrm{Ca}^{2+}$ sensor for release, but did not represent proof that $\mathrm{Ca}^{2+}$ binding to Syt1 triggers release, nor did it tell us which of the principal two biochemical activities of Syt1$\mathrm{Ca}^{2+}$-dependent phospholipid- and SNAREbinding-was involved in its function. Definitive evidence that Syt1, and by analogy other Syts, is indeed a $\mathrm{Ca}^{2+}$ sensor for release came from knockin experiments in which point mutations that selectively alter the $\mathrm{Ca}^{2+}$ affinity and specificity of $\mathrm{Ca}^{2+}$-dependent interactions were introduced into the endogenous mouse Syt1 (Fernández-Chacón et al. 2001; Pang et al. 2006). Biochemical studies revealed that the D232N mutation in the C2A-domain of Syt1 increases the strength of the $\mathrm{Ca}^{2+}$-dependent binding of the double C2-domain fragment to SNARE complexes without altering phospholipid binding, whereas both the R233Q mutation and, to a lesser degree, the D238N mutation decrease the apparent $\mathrm{Ca}^{2+}$ affinity of the double C2-domain fragment of Syt1 during phospholipid binding without major effects on SNARE-complex binding (FernándezChacón et al. 2001; Pang et al. 2006). Strikingly, the D232N mutation increased the apparent $\mathrm{Ca}^{2+}$ affinity of evoked neurotransmitter release (i.e., decreased the $\mathrm{Kd}$ for $\mathrm{Ca}^{2+}$ ), whereas the R233Q and the D232N decreased the apparent $\mathrm{Ca}^{2+}$ affinity of evoked release without changing the apparent $\mathrm{Ca}^{2+}$ cooperativity of release (Fig. 4A). Thus, changes in the apparent $\mathrm{Ca}^{2+}$ affinity of Syt1 lead to corresponding 
A

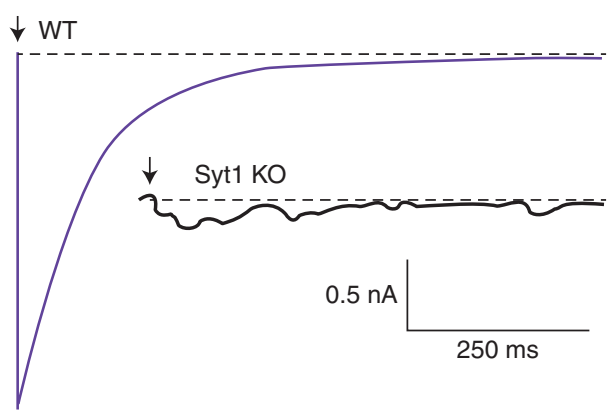

C

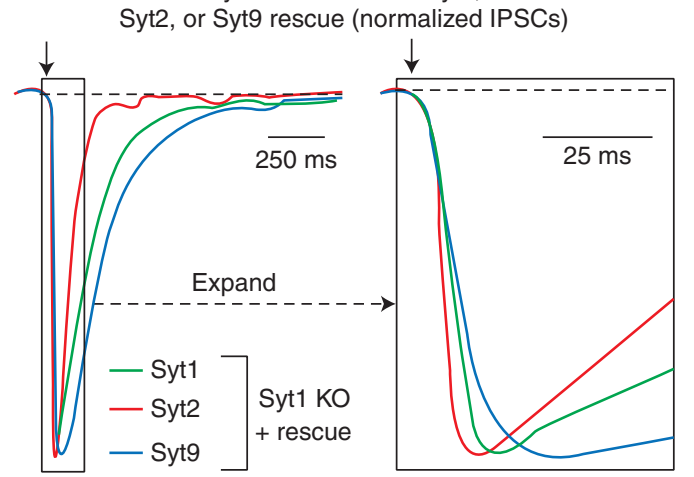

B

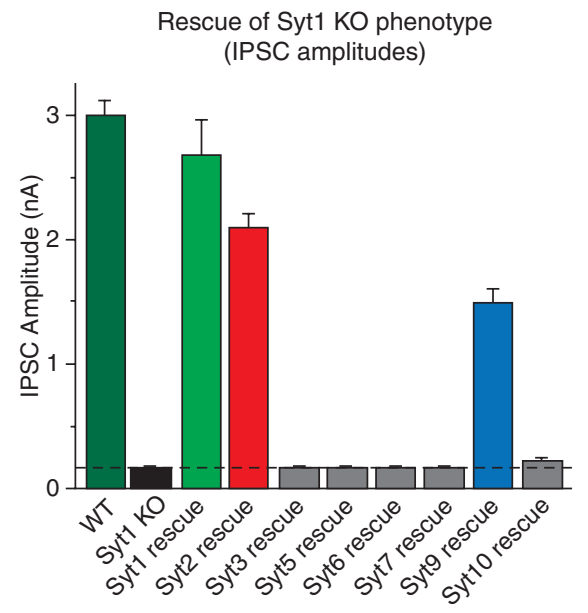

D IPSC kinetics

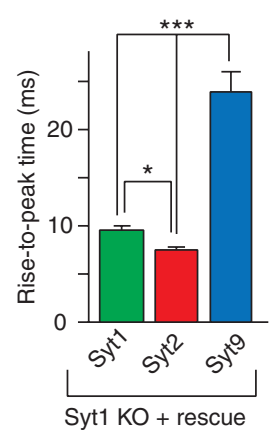

Figure 3. Syt1, Syt2, and Syt9 function as synaptic $\mathrm{Ca}^{2+}$ sensors for neurotransmitter release. (A) Deletion of Syt1 in cortical neurons blocks fast synchronous neurotransmitter release. Panels depict representative inhibitory postsynaptic currents (IPSCs) monitored in cortical neurons cultured from littermate wild-type (WT) and Syt1 knockout $($ Syt1 KO) neurons (arrow = action potential). These data and those shown in panels B-D were modified from Xu et al. (2007). (B) Screen of all $\mathrm{Ca}^{2+}$-binding synaptotagmin isoforms for their ability to rescue the loss of fast neurotransmitter release in Syt1 KO neurons. Data shown are means IPSC amplitudes ( \pm s.E.M.); note that only Syt1, 2, and 9 are capable of rescue. (C) Syt1, Syt2, and Syt9 mediate $\mathrm{Ca}^{2+}$ triggering of release with distinct kinetics. Data shown are representative IPSCs monitored in Syt1 KO neurons expressing Syt1, 2, or 9. IPSCs were normalized for the maximal amplitude. The traces on the right display an expanded part of the overall IPSCs depicted on the left. $(D)$ Quantitation of the kinetics of the increase in the IPSC (left, as mean rise time) and the decay of the IPSC (right, as mean time constant of the IPSC decay) triggered by $\mathrm{Ca}^{2+}$ binding to Syt 1,2 , or 9 . Note that IPSCs mediated by Syt 2 exhibit the fastest rise and decay kinetics, whereas IPSCs mediated by Syt 9 are twofold slower. All error bars indicate S.E.M.; asterisks indicate statistically significant differences as assessed by Student's $t$-test $\left({ }^{*} \mathrm{p}<0.05 ;{ }^{* *} \mathrm{p}<0.01{ }^{* * *} \mathrm{p}<0.001\right)$.

changes in the apparent $\mathrm{Ca}^{2+}$ affinity of release, proving that $\mathrm{Syt} 1$ is a true $\mathrm{Ca}^{2+}$ sensor. Moreover, these experiments show that both SNAREand phospholipid-binding by Syt 1 are involved in release, suggesting that $\mathrm{Ca}^{2+}$ binding to Syt1 triggers release by inducing a fast simultaneous interaction of Syt 1 with both SNARE complexes and with phospholipids.

$\mathrm{Ca}^{2+}$ binding to both C2-domains of Syt1 contributes to triggering release, although the two C2-domains are not equivalent. Mutations in the $\mathrm{C} 2 \mathrm{~B}$-domain $\mathrm{Ca}^{2+}$-binding sites block 
release similarly to the Syt $1 \mathrm{KO}$, whereas mutations in the $\mathrm{C} 2 \mathrm{~A}$-domain $\mathrm{Ca}^{2+}$-binding sites have a much less severe effect (Mackler and Reist 2001; Stevens and Sullivan 2003; Shin et al. 2009). Initially it was hypothesized that the $\mathrm{C} 2 \mathrm{~A}$-domain $\mathrm{Ca}^{2+}$-binding sites are of little importance, but careful $\mathrm{Ca}^{2+}$ titrations revealed that blocking $\mathrm{Ca}^{2+}$ binding to the $\mathrm{C} 2 \mathrm{~A}$-domain not only decreases the magnitude of release, but also decreases the apparent $\mathrm{Ca}^{2+}$ cooperativity of release (Shin et al. 2009). Among others, these experiments confirmed that the two C2domains of Syt 1 function cooperatively, and that $\mathrm{Ca}^{2+}$ binding to both $\mathrm{C} 2$-domains triggers release to achieve the high apparent cooperativity of $\mathrm{Ca}^{2+}$ triggering of release (Meinrenken et al. 2003).

\section{SYNAPTOTAGMINS AS $\mathrm{Ca}^{2+}$ SENSORS FOR SPONTANEOUS RELEASE}

In a typical central neuron, spontaneous release events add up over time to a sizable signal, and may have an important physiological role (McKinney et al. 1999; Carter and Regehr 2002; Sutton et al. 2006). Most spontaneous release is $\mathrm{Ca}^{2+}$ dependent, suggesting it is regulated (Xu et al. 2009). Although spontaneous release was traditionally considered to be determined primarily if not exclusively by the number of synapses and the release probability of these synapses, increasing evidence indicates that spontaneous release may be derived from a vesicle pool that is different from that used for evoked release (Sara et al. 2005), and that it does not always, and possibly not even in most cases, correlate with the number of synapses and their release probability.

The $\mathrm{Ca}^{2+}$ dependence of spontaneous release suggested that a $\mathrm{Ca}^{2+}$ sensor should trigger it. The logical choice for such a $\mathrm{Ca}^{2+}$ sensor would be Syt 1 and its homologs. Indeed, analysis of the $\mathrm{Ca}^{2+}$ dependence of spontaneous release in knockin mutant mice in which the affinity and binding-specificity of the Syt 1 $\mathrm{Ca}^{2+}$-binding sites were altered revealed that increases in the $\mathrm{Ca}^{2+}$-dependent interaction of Syt1 with SNARE complexes induced by the $\mathrm{D} 232 \mathrm{~N}$ mutation caused an increase in the apparent $\mathrm{Ca}^{2+}$ affinity of spontaneous release (Fig. 4B; Xu et al. 2009). Conversely, decreases in the apparent $\mathrm{Ca}^{2+}$ affinity of Syt1 during phospholipid binding induced by the R233Q or the D238N mutation caused a decrease in the apparent $\mathrm{Ca}^{2+}$ affinity of spontaneous release (Fig. 4B). These results indicated that Syt 1 functions as a $\mathrm{Ca}^{2+}$ sensor for spontaneous release, consistent with the previous finding that other elements of the canonical release machinery (e.g., SNARE proteins, Munc18-1, Munc13, and RIMs) are similarly involved.

However, deletion of Syt1 produces a large increase in spontaneous release frequency instead of blocking spontaneous release (Littleton et al. 1994; Maximov and Südhof 2005), suggesting that Syt1 is a clamp for spontaneous release instead of a $\mathrm{Ca}^{2+}$ sensor. This apparently contradictory observation was explained when it was found that the increased spontaneous release in Syt1 KO neurons was also completely $\mathrm{Ca}^{2+}$ dependent, but exhibited a higher apparent $\mathrm{Ca}^{2+}$ affinity and a lower apparent $\mathrm{Ca}^{2+}$ cooperativity than spontaneous release triggered by $\mathrm{Ca}^{2+}$ binding to Syt1 (Xu et al. 2009). Thus, deletion of Syt1 unmasked a secondary $\mathrm{Ca}^{2+}$ sensor with different properties that was normally clamped by Syt 1 . The nature of this $\mathrm{Ca}^{2+}$ sensor remains unclear, but it may be the same as the $\mathrm{Ca}^{2+}$ sensor that triggers asynchronous release and that has similar properties (Sun et al. 2007).

In addition to Syts, Doc2 proteins were implicated in regulating spontaneous release. KO or shRNA-mediated knockdown of Doc2 proteins, which are $\mathrm{Ca}^{2+}$-binding proteins related to Syts that also bind to SNAREs and to phospholipids, decreases spontaneous release significantly (Groffen et al. 2010; Pang et al. 2011). Interestingly, the Doc $2 \mathrm{KO}$ and knockdown had no effect on evoked release, confirming the differential nature of spontaneous and evoked release. Although the $\mathrm{Ca}^{2+}$-binding properties of Doc2 proteins suggested that they may function as $\mathrm{Ca}^{2+}$ sensors for spontaneous exocytosis (Groffen et al. 2010), the decrease in mini frequency induced by Doc2 knockdown was fully rescued by expression of Doc2 proteins lacking $\mathrm{Ca}^{2+}$-binding sites, 

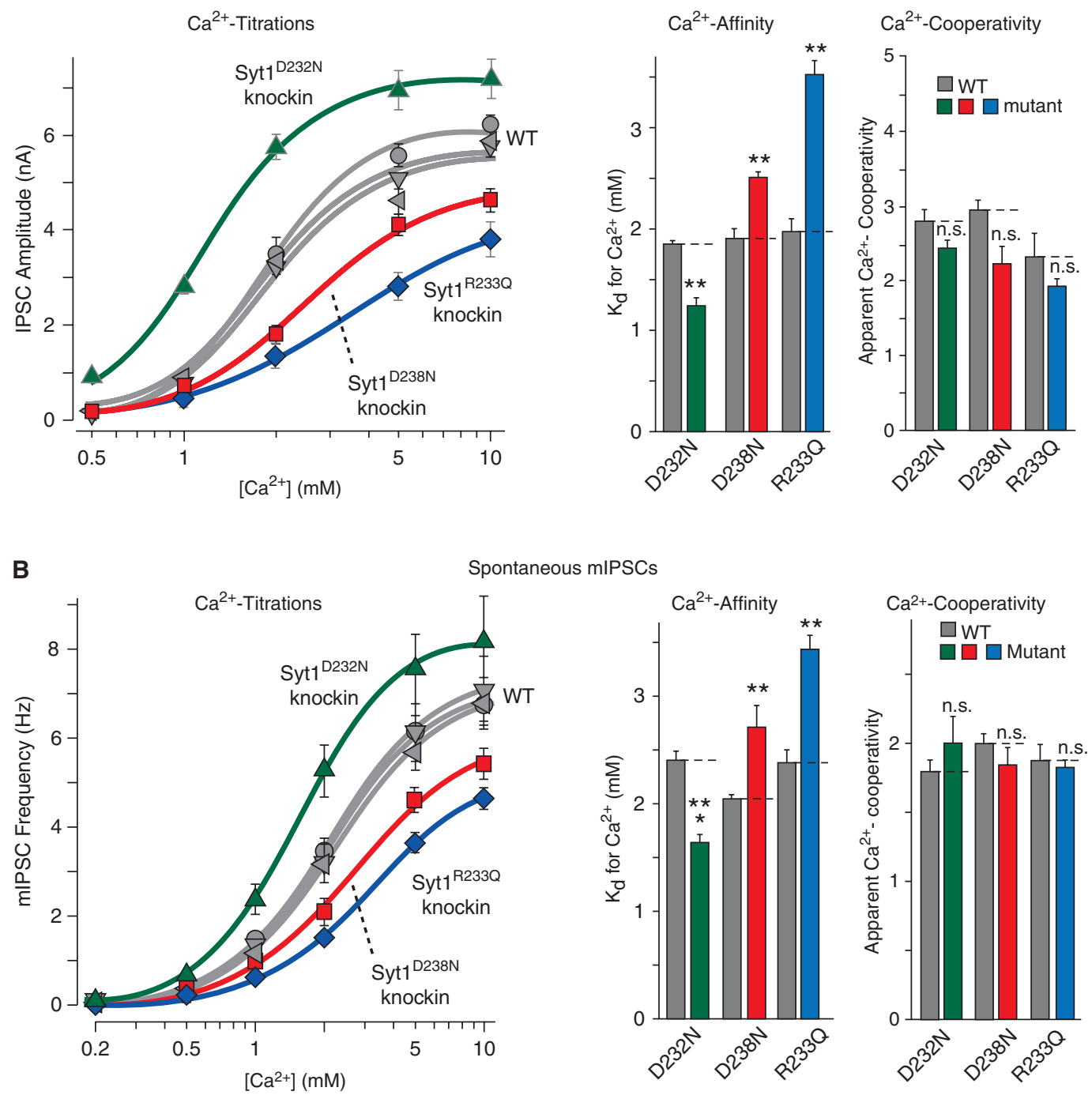

Figure 4. Syt1 $\mathrm{Ca}^{2+}$-binding site point mutations illustrate Syt1 function as a $\mathrm{Ca}^{2+}$ sensor for evoked and spontaneous neurotransmitter release. (A) Evoked IPSCs measured in neurons cultured from knockin mice carrying single amino-acid substitutions in the $\mathrm{Ca}^{2+}$-binding site of the Syt1 C2A-domain. Three knockin mice, each with an individual littermate control (gray) were analyzed: mice with the D232N substitution that increases the amount of $\mathrm{Ca}^{2+}$-stimulated SNARE-complex binding by Syt1 (green; Pang et al. 2006); the R233Q substitution that greatly decreases the apparent $\mathrm{Ca}^{2+}$ affinity of Syt1 during phospholipid binding (blue; FernándezChacón et al. 2001); and the D238N substitution that modestly decreases the apparent $\mathrm{Ca}^{2+}$ affinity of Syt1 (red; Pang et al. 2006). Action-potential evoked IPSCs were measured at the indicated concentrations of extracellular $\mathrm{Ca}^{2+}$; the plot on the left depicts the absolute IPSC amplitude as a function of the extracellular $\mathrm{Ca}^{2+}$ concentration, whereas the summary graphs on the right display the parameters for the apparent $\mathrm{Ca}^{2+}$ affinity and $\mathrm{Ca}^{2+}$ cooperativity of release obtained by fitting individual $\mathrm{Ca}^{2+}$ titration experiments to a Hill function. $(B)$ Same as $(A)$, except that the frequency of spontaneous release events was measured. For both $(A)$ and $(B)$, data are means \pm S.E.M. (Figure is adapted from Xu et al. 2007.) 
indicating that Doc2 proteins do not function as $\mathrm{Ca}^{2+}$ sensors for spontaneous exocytosis (Pang et al. 2011). Moreover, the Doc2 knockdown had no effect on the increased spontaneous release observed in Syt1 KO neurons, and also did not affect asynchronous release, suggesting that Doc2 proteins do not function in these types of release.

\section{COMPLEXINS AS SYNAPTOTAGMIN SIDEKICKS}

Complexins were identified as SNARE-complex binding proteins, giving rise to their name (McMahon et al. 1995). Complexins are small soluble proteins of approximately 120 residues that are evolutionarily conserved in all animals similar to synaptotagmins. The crystal structure of complexin bound to the assembled SNARE complex revealed that complexin contains a central short $\sim 20$-residue $\alpha$-helix that nestles into the groove formed by the synaptobrevin and syntaxin SNARE motifs in the SNARE complex (Chen et al. 2002). In addition, complexin contains a similarly short accessory amino-terminal $\alpha$-helix that does not contact the SNARE complex in the crystal structure, with amino- and carboxy-terminal unstructured sequences flanking the two helices. Interestingly, complexin binds to the SNARE complex in an antiparallel orientation at a membrane-proximal site of the complex, suggesting that complexin can only bind to the SNARE complex after it has assembled to more than $50 \%$.

Mammals express four complexin isoforms, two that are widely distributed in the body and abundant in brain (complexin-1 and -2; McMahon et al. 1995), and two additional isoforms that are enriched in retina (complexin-3 and -4; Reim et al. 2005). Complexin-3 and -4 include a carboxy-terminal isoprenylation sequence that is absent from complexin-1 and -2 and likely attaches complexin-3 and -4 to the plasma membrane. Deletion of complexin-1 and -2 in mice led to a striking phenotype that represented a milder phenocopy of the Syt1 knockout phenotype, suggesting that complexins act in the same pathway as synaptotagmins (Reim et al. 2001). Specifically, these mice exhibited a selective but only partial loss of synchronous neurotransmitter release, without a major decrease in asynchronous release. Subsequent knockdown experiments using shRNAs confirmed this phenotype, but extended it to reveal an increase in spontaneous release analogous to that observed in Syt1 knockout neurons, with the same shift to a higher apparent $\mathrm{Ca}^{2+}$ affinity and lower apparent $\mathrm{Ca}^{2+}$ cooperativity (Maximov et al. 2009; Yang et al. 2010). Thus, complexins act both as activators and as clamps of neurotransmitter release. Moreover, unlike the Syt1 KO, which had no effect on the size of the readily-releasable pool, the complexin knockdown produced a $\sim 40 \%$ decrease in the readily-releasable pool (Yang et al. 2010). Rescue experiments revealed that SNARE-complex binding by complexin is essential for its function (Maximov et al. 2009). Moreover, such experiments showed that the complexin amino terminus is crucial for its activating role (Xue et al. 2007), whereas its accessory $\alpha$-helix mediates its clamping function (Maximov et al. 2009; Yang et al. 2010). Considerable controversy developed at one point about whether or not complexins have a clamping function, in that such function was not obvious in autapses (Reim et al. 2001), but was the only function observed in in vitro fusion assays (Giraudo et al. 2009). Although the activation function of complexin is likely more important overall than its clamping function, the fact that the two functions can be localized to distinct autonomously acting sequences in complexin (Maximov et al. 2009; Yang et al. 2010) and that both phenocopy a function observed for Syts strongly supports their physiological importance.

How do complexin and Syts act in promoting $\mathrm{Ca}^{2+}$ triggering of synaptic vesicle fusion? Biochemical data indicate that the central $\alpha$-helix of complexin and Syt1 bind to SNARE complexes at overlapping sites, and that $\mathrm{Ca}^{2+}$ binding to Syt1 triggers the displacement of the central $\alpha$-helix of complexin from its binding site on SNARE complexes (Tang et al. 2006). Based on these electrophysiological and biochemical studies, a plausible current model is that complexin binding to primed synaptic 
vesicles containing partially assembled SNARE complexes "superprimes" these vesicles into an activated state, and simultaneously clamps them (Fig. 5). $\mathrm{Ca}^{2+}$ binding to synaptotagmin then triggers synaptotagmin binding to the SNARE complex and the phospholipid bilayer, dislodging the complexin clamp and pulling on the SNARE complex, thereby opening the fusion pore. This model accounts for most of the existing data, although it offers no explanation for the clamping function of synaptotagmin, and thus is unlikely to be definitive.

\section{SYNAPTOTAGMINS AS $\mathrm{Ca}^{2+}$ SENSORS FOR OTHER FORMS OF EXOCYTOSIS}

Many forms of exocytosis are induced by $\mathrm{Ca}^{2+}$, including hormone exocytosis in endocrine cells such as chromaffin cells, neuropeptide secretion in neurons, mast cell degranulation, and the acrosome reaction in sperm. Strikingly, for most of these forms of exocytosis the same Syts that mediate synaptic vesicle fusion (Syt1, Syt2, and Syt9) appear to be involved; in addition, Syt7 was also shown to play a central role. Specifically, for chromaffin granule exocytosis in chromaffin cells, nearly all $\mathrm{Ca}^{2+}$ triggering is mediated in equal parts by Syt 1 and Syt7, such that only the double Syt $1 / 7 \mathrm{KO}$ has a major phenotype in exocytosis (Schonn et al. 2008). In contrast, in pancreatic insulin- and glucagon-secreting cells, Syt7 appears to be the dominant $\mathrm{Ca}^{2+}$ sensor (Gustavsson et al. 2008,2009 ), whereas in mast cell degranulation, Syt2 is the most important $\mathrm{Ca}^{2+}$ sensor (Melicoff et al. 2009). In addition, Syt7 has been linked to exocytosis in non-neuronal cells, although it is not quite clear whether this is a physiological

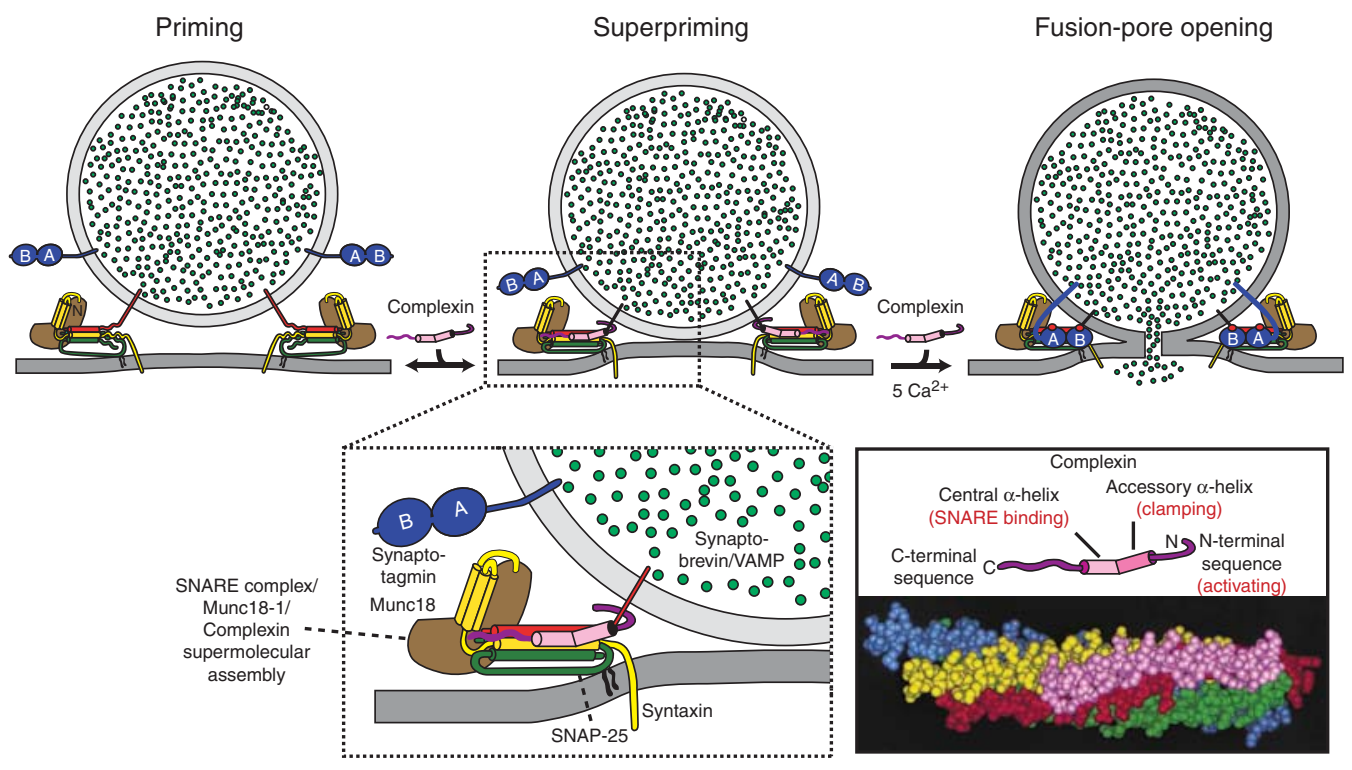

Figure 5. Schematic diagram of the mechanism of action of synaptotagmin and its complexin cofactor in $\mathrm{Ca}^{2+}$ triggered exocytosis. The top diagram displays the sequential priming of synaptic vesicles by partial SNARE/SM protein complex assembly, superpriming by binding of complexin to partially assembled SNARE complexes, and $\mathrm{Ca}^{2+}$ triggering of fusion-pore opening by $\mathrm{Ca}^{2+}$ binding to synaptotagmin. The objects in the diagram approximate real-size relationships. The diagram on the bottom left depicts a cartoon of a partially assembled SNARE/SM protein complex with complexin bound. The functional domain structure of complexin is shown on the right, with a space-filling model of complexin bound to a SNARE complex at the bottom (pink, the two 〈-helices of complexin; yellow, syntaxin-1; red, synaptobrevin; green and blue, SNAP-25). (The model and the functional assignment of complexin sequences are modified from Maximov et al. 2009; the complexin/SNARE complex crystal structure is modified from Chen et al. 2002.) 
T.C. Südhof
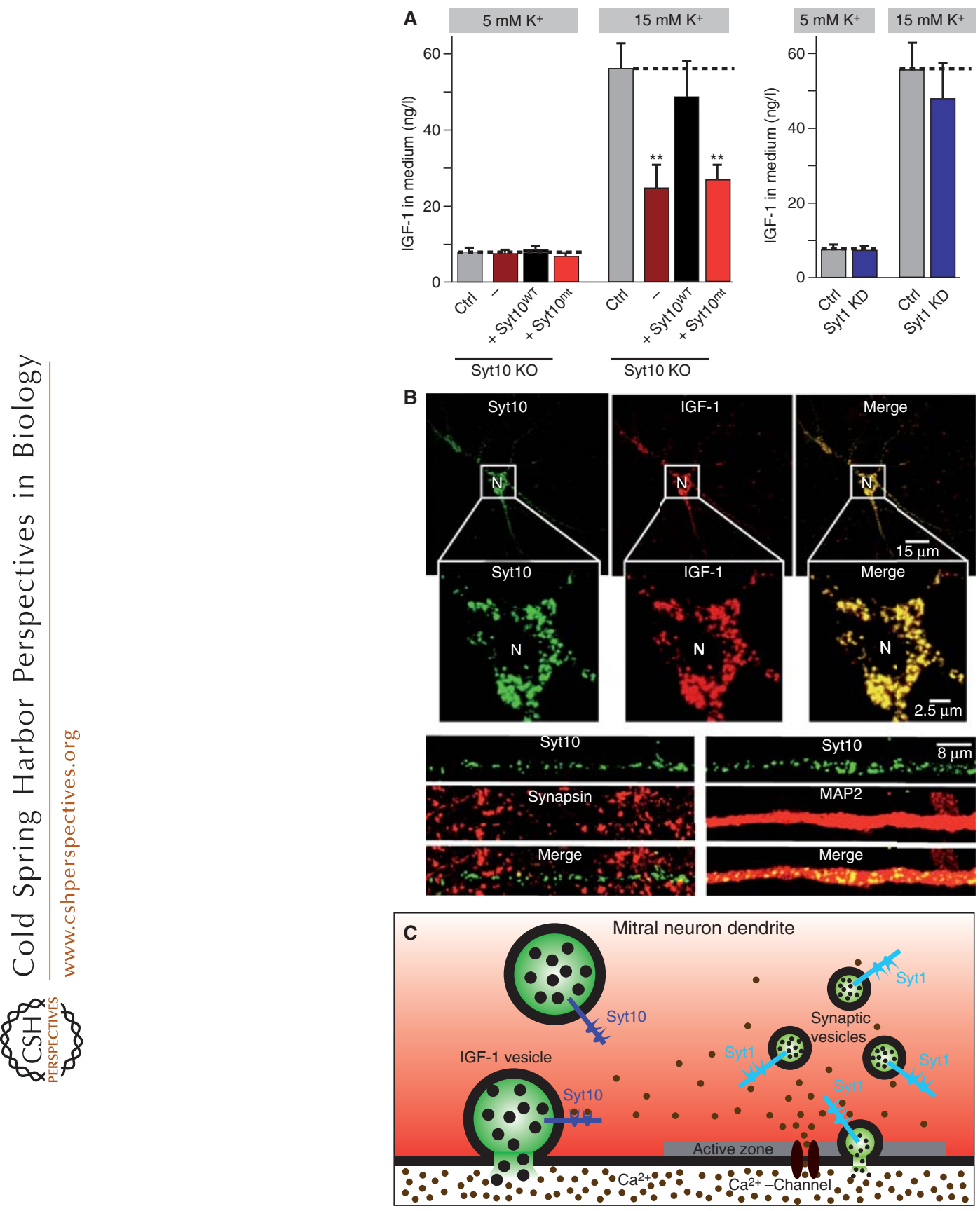

Figure 6. Illustration of distinct but similar functions of different synaptotagmins: Syt 10 acts as a $\mathrm{Ca}^{2+}$ sensor for IGF-1 containing vesicles in mitral neurons from olfactory bulb. (A) IGF-1 secretion from cultured olfactory bulb neurons is stimulated by depolarization with $15 \mathrm{~mm} \mathrm{KCl}$, but impaired by deletion of Syt 10 (this and the following panels were modified from Cao et al. 2011). (B) Syt10 colocalizes with IGF-1 containing vesicles in the somatodendritic regions of cultured mitral neurons. Images show double immunofluorescence labeling of tagged Syt 10 and either IGF-1, synapsin, or MAP2 as indicated. $(C)$ Illustration of the distinct functions of Syt1 and Syt10 as $\mathrm{Ca}^{2+}$ sensors exclusively for synaptic and IGF-1-containing vesicles, respectively, in mitral neurons. 
event (Martinez et al. 2000; Jaiswal et al. 2004; Wang and Hilgemann 2008). At least in chromaffin cells, complexins are obligatory cofactors for Syt-triggered exocytosis (Cai et al. 2008). Thus, despite the different kinetics of various types of exocytosis and the different localizations of various Syts, the same Syt paradigm appears to widely operate for all of these forms of exocytosis.

Until recently, no definitive function was identified for the second class of $\mathrm{Ca}^{2+}$-binding Syts that contain amino-terminal disulfide bonds, which lead to constitutive dimerization (Fig. 2A). These Syts exhibit a higher apparent $\mathrm{Ca}^{2+}$ affinity than Syt1, and also interact with phospholipids and SNAREs in a $\mathrm{Ca}^{2+}$-dependent manner ( $\mathrm{Li}$ et al. 1995; Sugita et al. 2002), suggesting that they may also function as $\mathrm{Ca}^{2+}$ sensors in exocytosis. This hypothesis was recently confirmed for Syt10, which was identified as the $\mathrm{Ca}^{2+}$ sensor for exocytosis of IGF-1 containing secretory vesicles in mitral neurons from the olfactory bulb (Cao et al. 2011). Interestingly, in the same neurons Syt1 functions as the $\mathrm{Ca}^{2+}$ sensor for synaptic vesicle exocytosis, and the two Syts act completely independently of each other (Fig. 6). Thus, different synaptotagmin isoforms can operate in the same cell to mediate the $\mathrm{Ca}^{2+}$-regulated fusion of distinct types of secretory vesicles.

\section{CONCLUSIONS}

Over the last two decades, a universal mechanism by which $\mathrm{Ca}^{2+}$ binding to Syts triggers fusion has emerged. This process involves a pas de deux of Syts and complexin, which act simultaneously on SNARE complexes and phospholipid membranes. The mechanism ensures the millisecond control of neurotransmitter release from presynaptic terminals on arrival of an action potential, but goes far beyond the synapse. The mechanism similarly applies to many other $\mathrm{Ca}^{2+}$-induced secretory events, as exemplified by the role of Syts and complexins in neuroendocrine secretion including IGF-1 exocytosis, and might further extend to all $\mathrm{Ca}^{2+}$-regulated membrane trafficking events in general.

\section{ACKNOWLEDGMENTS}

This work was supported by the Howard Hughes Medical Institute and by grants from the NIMH.

\section{REFERENCES}

Andrews NW, Chakrabarti S. 2005. There's more to life than neurotransmission: The regulation of exocytosis by synaptotagmin VII. Trends Cell Biol 15: 626-631.

Augustine GJ, Charlton MP, Smith SJ. 1985. Calcium entry and transmitter release at voltage-clamped nerve terminals of squid. J Physiol 367: 163-181.

Barber CF, Jorquera RA, Melom JE, Littleton JT. 2009. Postsynaptic regulation of synaptic plasticity by synaptotagmin 4 requires both $\mathrm{C} 2$ domains. J Cell Biol 187: 295-310.

Bennett MK, Calakos N, Scheller RH. 1992. Syntaxin: A synaptic protein implicated in docking of synaptic vesicles at presynaptic active zones. Science 257: 255-259.

Brose N, Petrenko AG, Südhof TC, Jahn R. 1992. Synaptotagmin: $\mathrm{A} \mathrm{Ca}^{2+}$ sensor on the synaptic vesicle surface. Science 256: 1021-1025.

Butz S, Fernández-Chacón R, Schmitz F, Jahn R, Südhof TC. 1999. The subcellular localizations of atypical synaptotagmins: Synaptotagmin III is enriched in synapses and synaptic plasma membranes but not in synaptic vesicles. J Biol Chem 274: 18290-18296.

Cai H, Reim K, Varoqueaux F, Tapechum S, Hill K, Sørensen JB, Brose N, Chow RH. 2008. Complexin II plays a positive role in $\mathrm{Ca}^{2+}$-triggered exocytosis by facilitating vesicle priming. Proc Natl Acad Sci 105: 19538-19543.

Cao P, Maximov A, Südhof TC. 2011. Activity-dependent IGF-1 exocytosis is controlled by the $\mathrm{Ca}^{2+}$-sensor synaptotagmin-10. Cell 145: 300-311.

Carter AG, Regehr WG. 2002. Quantal events shape cerebellar interneuron firing. Nat Neurosci 5: 1309-1318.

Chapman ER, Hanson PI, An S, Jahn R. 1995. $\mathrm{Ca}^{2+}$ regulates the interaction between synaptotagmin and syntaxin 1 . J Biol Chem 270: 23667-23671.

Chen X, Tomchick DR, Kovrigin E, Arac D, Machius M, Südhof TC, Rizo J. 2002. Three-dimensional structure of the complexin/SNARE complex. Neuron 33: 397-409.

Coussens L, Parker PJ, Rhee L, Yang-Feng TL, Chen E, Waterfield MD, Francke U, Ullrich A. 1986. Multiple, distinct forms of bovine and human protein kinase $\mathrm{C}$ suggest diversity in cellular signaling pathways. Science 233: $859-866$.

Dai H, Shin O-K, Machius M, Tomchick DR, Südhof TC, Rizo J. 2004. Structural basis for the evolutionary inactivation of $\mathrm{Ca}^{2+}$-binding to synaptotagmin 4 . Nature Struct Mol Biol 11: 844-849.

Davletov BA, Südhof TC. 1993. A single C2-domain from synaptotagmin I is sufficient for high affinity $\mathrm{Ca}^{2+/-}$ phospholipid-binding. J Biol Chem 268: 26386-26390.

Dean C, Liu H, Dunning FM, Chang PY, Jackson MB, Chapman ER. 2009. Synaptotagmin-IV modulates synaptic 
T.C. Südhof

function and long-term potentiation by regulating BDNF release. Nat Neurosci 12: 767-776.

Fatt P, Katz B. 1952. Spontaneous subthreshold activity at motor nerve endings. J Physiol 117: 109-128.

Fernandez I, Arac D, Ubach J, Gerber SH, Shin O, Gao Y, Anderson RGW, Südhof TC, Rizo J. 2001. Threedimensional structure of the synaptotagmin $1 \mathrm{C}_{2-}$ B-domain: Synaptotagmin 1 as a phospholipid binding machine. Neuron 32: 1057-1069.

Fernández-Chacón R, Königstorffer A, Gerber SH, Garcia J, Matos MF, Stevens CF, Brose N, Rizo J Rosenmund C, Südhof TC. 2001. Synaptotagmin I functions as a $\mathrm{Ca}^{2+}$ regulator of release probability. Nature 410: 41-49.

Fukuda M, Kanno E, Mikoshiba K. 1999. Conserved N-terminal cysteine motif is essential for homo- and heterodimer formation of synaptotagmins III, V, VI, and X. J Biol Chem 274: 31421-31427.

Geppert M, Goda Y, Hammer RE, Li C, Rosahl TW, Stevens CF, Südhof TC. 1994. Synaptotagmin I: A major $\mathrm{Ca}^{2+}$ sensor for transmitter release at a central synapse. Cell 79: 717-727.

Giraudo CG, Garcia-Diaz A, Eng WS, Chen Y, Hendrickson WA, Melia TJ, Rothman JE. 2009. Alternative zippering as an on-off switch for SNARE-mediated fusion. Science 323: $512-516$.

Groffen AJ, Martens S, Diez Arazola R, Cornelisse LN, Lozovaya N, de Jong AP, Goriounova NA, Habets RL, Takai Y, Borst JG, et al. 2010. Doc2b is a high-affinity $\mathrm{Ca}^{2+}$ sensor for spontaneous neurotransmitter release. Science 327: 1614-1618.

Gustavsson N, Lao Y, Maximov A, Chuang JC, Kostromina E, Repa JJ, Li C, Radda GK, Südhof TC, Han W. 2008. Impaired insulin secretion and glucose intolerance in synaptotagmin-7 null mutant mice. Proc Natl Acad Sci 105: 3992-3997.

Gustavsson N, Wei SH, Hoang DN, Lao Y, Zhang Q, Radda GK, Rorsman P, Südhof TC, Han W. 2009. Synaptotagmin-7 is a principal $\mathrm{Ca}^{2+}$ sensor for $\mathrm{Ca}^{2+}$-induced glucagon exocytosis in pancreas. J Physiol 587: 1169-1178.

Han W, Rhee JS, Maximov A, Lao Y, Mashimo T, Rosenmund C, Südhof TC. 2004. N-glycosylation is essential for vesicular targeting of synaptotagmin 1 . Neuron 41: 85-99.

Hefft S, Jonas P. 2005. Asynchronous GABA release generates long-lasting inhibition at a hippocampal interneuron-principal neuron synapse. Nat Neurosci 8: 1319-1328.

Hui E, Bai J, Wang P, Sugimori M, Llinas RR, Chapman ER. 2005. Three distinct kinetic groupings of the synaptotagmin family: Candidate sensors for rapid and delayed exocytosis. Proc Natl Acad Sci 102: 5210-5214.

Jaiswal JK, Chakrabarti S, Andrews NW, Simon SM. 2004. Synaptotagmin VII restricts fusion pore expansion during lysosomal exocytosis. PLoS Biol 2: E233.

Katz B, Miledi R. 1967. Ionic requirements of synaptic transmitter release. Nature 215: 651.

Li C, Ullrich B, Zhang ZZ, Anderson RGW, Brose N, Südhof TC. 1995. $\mathrm{Ca}^{2+}$-dependent and $\mathrm{Ca}^{2+}$-independent activities of neural and nonneural synaptotagmins. Nature 375: 594-599.
Littleton JT, Stern M, Perin M, Bellen HJ. 1994. Calcium dependence of neurotransmitter release and rate of spontaneous vesicle fusions are altered in Drosophila synaptotagmin mutants. Proc Natl Acad Sci 91: 10888-10892.

Littleton JT, Serano TL, Rubin GM, Ganetzky B, Chapman ER. 1999. Synaptic function modulated by changes in the ratio of synaptotagmin I and IV. Nature 400: $757-760$.

Mackler JM, Reist NE. 2001. Mutations in the second C2 domain of synaptotagmin disrupt synaptic transmission at Drosophila neuromuscular junctions. J Comp Neurol 436: $4-16$.

Martinez I, Chakrabarti S, Hellevik T, Morehead J, Fowler K, Andrews NW. 2000. Synaptotagmin VII regulates $\mathrm{Ca}^{2+}$ dependent exocytosis of lysosomes in fibroblasts. J Cell Biol 148: 1141-1149.

Maximov A, Südhof TC. 2005. Autonomous function of synaptotagmin 1 in triggering synchronous release independent of asynchronous release. Neuron 48: 547-554.

Maximov A, Shin O-H, Südhof TC. 2007. Synaptotagmin12 , a synaptic vesicle phosphoprotein that modulates spontaneous neurotransmitter release. J Cell Biol 176: $113-124$.

Maximov A, Tang J, Yang X, Pang Z, Südhof TC. 2009. Complexin controls the force transfer from SNARE complexes to membranes in fusion. Science 323: 516-521.

McKinney RA, Capogna M, Dürr R, Gähwiler BH, Thompson SM. 1999. Miniature synaptic events maintain dendritic spines via AMPA receptor activation. Nat Neurosci 2: 44-49.

McMahon HT, Missler M, Li C, Südhof TC. 1995. Complexins: Cytosolic proteins that regulate SNAP-receptor function. Cell 83: 111-119.

Meinrenken CJ, Borst JG, Sakmann B. 2003. Local routes revisited: The space and time dependence of the $\mathrm{Ca}^{2+}$ signal for phasic transmitter release at the rat calyx of Held. J Physiol 547: 665-689.

Melicoff E, Sansores-Garcia L, Gomez A, Moreira DC, Datta P, Thakur P, Petrova Y, Siddiqi T, Murthy JN, Dickey BF, et al. 2009. Synaptotagmin-2 controls regulated exocytosis but not other secretory responses of mast cells. J Biol Chem 284: 19445-19451.

Pang ZP, Südhof TC. 2010. Cell biology of $\mathrm{Ca}^{2+}$-triggered exocytosis. Curr Opinion Cell Biol 22: 496-505.

Pang ZP, Shin O-H, Meyer AC, Rosenmund C, Südhof TC. 2006. A gain-of-function mutation in synaptotagmin-1 reveals a critical role of $\mathrm{Ca}^{2+}$-dependent SNAREcomplex binding in synaptic exocytosis. J Neurosci 26: 12556-12565.

Pang ZP, Bacaj T, Yang X, Zhou P, Xu W, Südhof TC. 2011. Doc2 supports spontaneous synaptic transmission by a calcium-independent mechanism. Neuron 70: 244-251.

Perin MS, Fried VA, Mignery GA, Jahn R, Südhof TC. 1990. Phospholipid binding by a synaptic vesicle protein homologous to the regulatory region of protein kinase C. Nature 345: 260-263.

Reim K, Mansour M, Varoqueaux F, McMahon HT, Südhof TC, Brose N, Rosenmund C. 2001. Complexins regulate the $\mathrm{Ca}^{2+}$ sensitivity of the synaptic neurotransmitter release machinery. Cell 104: 71-81. 
Reim K, Wegmeyer H, Brandstätter JH, Xue M, Rosenmund C, Dresbach T, Hofmann K, Brose N. 2005. Structurally and functionally unique complexins at retinal ribbon synapses. J Cell Biol 169: 669-680.

Sabatini BL, Regehr WG. 1996. Timing of neurotransmission at fast synapses in the mammalian brain. Nature 384: $170-172$.

Sara Y, Virmani T, Deák F, Liu X, Kavalali ET. 2005. An isolated pool of vesicles recycles at rest and drives spontaneous neurotransmission. Neuron 45: 563-573.

Schonn JS, Maximov A, Lao Y, Südhof TC, Sorensen JB, 2008. Synaptotagmin- 1 and -7 are functionally overlapping $\mathrm{Ca}^{2+}$ sensors for exocytosis in adrenal chromaffin cells. Proc Natl Acad Sci 105: 3998-4003.

Shao X, Davletov BA, Sutton RB, Südhof TC, Rizo J. 1996. Bipartite $\mathrm{Ca}^{2+}$-binding motif in $\mathrm{C}_{2}$ domains of synaptotagmin and protein kinase C. Science 273: 248-251.

Shin O-H, Xu J, Rizo J, Südhof TC. 2009. Differential but convergent functions of $\mathrm{Ca}^{2+}$-binding to synaptotagmin-1 C2-domains mediate neurotransmitter release. Proc Natl Acad Sci 106: 16469-16474.

Stevens CF, Sullivan JM. 2003. The synaptotagmin C2A domain is part of the calcium sensor controlling fast synaptic transmission. Neuron 39: 299-308.

Sun J, Pang ZP, Qin D, Fahim AT, Adachi R, Südhof TC. 2007. A dual $\mathrm{Ca}^{2+}$-sensor model for neuro-transmitter release in a central synapse. Nature 450: 676-682.

Südhof TC. 2002. Synaptotagmins: Why so many? J Biol Chem 277: 7629-7632.

Südhof TC. 2004. The synaptic vesicle cycle. Annu Rev Neurosci 27: 509-547.

Sugita S, Shin O-H, Han W, Lao Y, Südhof TC. 2002. Synaptotagmins form hierarchy of exocytotic $\mathrm{Ca}^{2+}$-sensors with distinct $\mathrm{Ca}^{2+}$-affinities. EMBO J 21: 270-280.

Sutton AB, Davletov BA, Berghuis AM, Südhof TC, Sprang SR. 1995. Structure of the first C2-domain of synaptotagmin I: A novel $\mathrm{Ca}^{2+} /$ phospholipid binding fold. Cell 80: $929-938$.

Sutton RB, Ernst JA, Brunger AT. 1999. Crystal structure of the cytosolic C2A-C2B domains of synaptotagmin III.

\section{Calcium Control of Neurotransmitter Release}

Implications for $\mathrm{Ca}^{2+}$-independent snare complex interaction. J Cell Biol 147: 589-598.

Sutton MA, Ito HT, Cressy P, Kempf C, Woo JC, Schuman EM. 2006. Miniature neurotransmission stabilizes synaptic function via tonic suppression of local dendritic protein synthesis. Cell 125: 785-799.

Tang J, Maximov A, Shin O-H, Dai H, Rizo J, Südhof TC. 2006. A complexin/synaptotagmin-1 switch controls fast synaptic vesicle exocytosis. Cell 126: 1175-1187.

Ubach J, Zhang X, Shao X, Südhof TC, Rizo J. 1998. $\mathrm{Ca}^{2+}$ binding to synaptotagmin: How many $\mathrm{Ca}^{2+}$ ions bind to the tip of a C2-domain? EMBO J 17: 3921-3930.

Von Poser C, Ichtchenko K, Shao X, Rizo J, Südhof TC. 1997. The evolutionary pressure to inactivate: A subclass of synaptotagmins with an amino acid substitution that abolishes $\mathrm{Ca}^{2+}$ binding. J. Biol Chem 272: 1431414319 .

Wang TM, Hilgemann DW. 2008. Ca-dependent nonsecretory vesicle fusion in a secretory cell. J Gen Physiol 132: 51-65.

Wang CT, Lu JC, Bai J, Chang PY, Martin TF, Chapman ER, Jackson MB. 2003. Different domains of synaptotagmin control the choice between kiss-and-run and full fusion. Nature 424: 943-947.

Xu J, Mashimo T, Südhof TC. 2007. Synaptotagmin-1, -2, and $-9: \mathrm{Ca}^{2+}$-sensors for fast release that specify distinct presynaptic properties in subsets of neurons. Neuron 54: $801-812$.

Xu J, Pang ZP, Shin OH, Südhof TC. 2009. Synaptotagmin-1 functions as a $\mathrm{Ca}^{2+}$ sensor for spontaneous release. Nat Neurosci 12: 759-766.

Xue M, Reim K, Chen X, Chao HT, Deng H, Rizo J, Brose N, Rosenmund C. 2007. Distinct domains of complexin I differentially regulate neurotransmitter release. Nat Struct Mol Biol 14: 949-958.

Yang X, Kaeser Woo YJ, Pang ZP, Xu W, Südhof TC. 2010. Complexin clamps asynchronous release by blocking a secondary $\mathrm{Ca}^{2+}$-sensor via its accessory-helix. Neuron 68: $907-920$. 


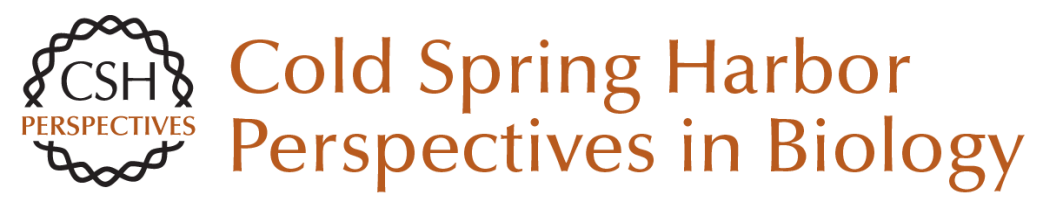

\section{Calcium Control of Neurotransmitter Release}

Thomas C. Südhof

Cold Spring Harb Perspect Biol 2012; doi: 10.1101/cshperspect.a011353 originally published online November 8, 2011

\section{Subject Collection The Synapse}

Studying Signal Transduction in Single Dendritic Spines Ryohei Yasuda

Synaptic Vesicle Pools and Dynamics AbdulRasheed A. Alabi and Richard W. Tsien

Synapses and Memory Storage Mark Mayford, Steven A. Siegelbaum and Eric $R$. Kandel

Synapses and Alzheimer's Disease Morgan Sheng, Bernardo L. Sabatini and Thomas C. Südhof

\section{Synaptic Cell Adhesion}

Markus Missler, Thomas C. Südhof and Thomas Biederer

Synaptic Dysfunction in Neurodevelopmental Disorders Associated with Autism and Intellectual Disabilities

Huda Y. Zoghbi and Mark F. Bear

The Postsynaptic Organization of Synapses Morgan Sheng and Eunjoon Kim

Presynaptic LTP and LTD of Excitatory and Inhibitory Synapses

Pablo E. Castillo
Synaptic Vesicle Endocytosis

Yasunori Saheki and Pietro De Camilli

Short-Term Presynaptic Plasticity Wade G. Regehr

NMDA Receptor-Dependent Long-Term

Potentiation and Long-Term Depression

(LTP/LTD) Christian Lüscher and Robert C. Malenka

Ultrastructure of Synapses in the Mammalian

Brain Kristen M. Harris and Richard J. Weinberg

Calcium Signaling in Dendritic Spines Michael J. Higley and Bernardo L. Sabatini

Synaptic Neurotransmitter-Gated Receptors Trevor G. Smart and Pierre Paoletti

Synaptic Vesicle Exocytosis

Thomas C. Südhof and Josep Rizo

Vesicular and Plasma Membrane Transporters for Neurotransmitters

Randy D. Blakely and Robert H. Edwards

For additional articles in this collection, see http://cshperspectives.cshlp.org/cgi/collection/

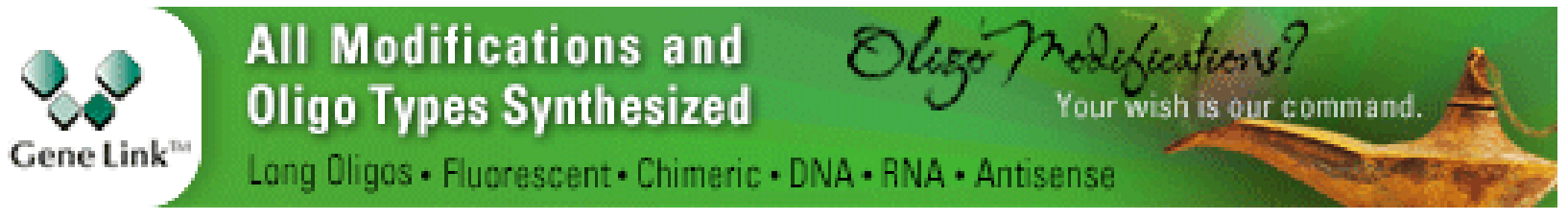

